\title{
Optima Control for SIR Model with The Influence of Vaccination, Quarantine and Immigration Factor
}

\section{Kontrol Optimal pada Model SIR dengan Pengaruh Vaksinasi, Karantina, dan Faktor Imigrasi}

\author{
'Susi Agustianingsih ${ }^{*},{ }^{*}$ Rina Reorita ${ }^{2},{ }^{*}$ Renny $^{3}$
}

\begin{abstract}
The SIR model is one of the mathematical model which describes the characteristic of the spread of infectious disease in differential equation form by dividing the human populations into three groups. There are individual susceptible group, individual infective group, and individual recovered group. This model involves vaccination, quarantine, and immigration factors. Vaccination and quarantine must be given as much as it needs, so a control is required to minimize infection of disease and the number of individual infective with a minimum costs. In this research, optimal control of SIR model with vaccination, quarantine, and immigration factor is solved by using Pontryagin maximum principle and numerically simulated by using Runge-Kutta method. Numerical simulation results show optimal control of treatment, citizen of vaccination, immigrant of vaccination, and quarantine will accelerate the decline of infected number with the minimum cost, compared with the optimal control of SIR model without quarantine factor.
\end{abstract}

Keywords: Quarantine, optimal control, SIR model, Pontryagin maximum principle, vaccination.

\begin{abstract}
Abstrak
Model SIR adalah salah satu model matematika yang menggambarkan sifat penyebaran penyakit menular dalam bentuk persamaan diferensial dengan membagi populasi manusia menjadi tiga kelompok individu, yaitu kelompok individu rentan (susceptible), kelompok individu terinfeksi (infective), dan kelompok individu sembuh (recovery). Model ini dipengaruhi oleh vaksinasi, karantina, dan faktor imigrasi. Pemberian vaksin dan karantina harus diberikan sesuai kebutuhan, sehingga perlu dilakukan kontrol untuk meminimalisir penularan penyakit dan jumlah individu terinfeksi dengan biaya minimum. Dalam penelitian ini, dibahas kontrol optimal model SIR dengan pengaruh vaksinasi, karantina, dan faktor imigrasi menggunakan prinsip maksimum Pontryagin serta disimulasikan secara numerik dengan metode Runge-Kutta. Hasil simulasi numerik menunjukkan bahwa adanya kontrol optimal pengobatan, kontrol optimal vaksinasi untuk warga negara, kontrol optimal vaksinasi untuk imigran, dan kontrol optimal karantina dapat mempercepat penurunan jumlah individu terinfeksi dengan biaya yang lebih minimum dibandingkan dengan kontrol optimal pada model SIR tanpa faktor karantina.
\end{abstract}

Kata kunci: Karantina, kontrol optimal, model SIR, prinsip maksimum Pontryagin, vaksinasi.

*Jurusan Matematika, Universitas Jenderal Soedirman

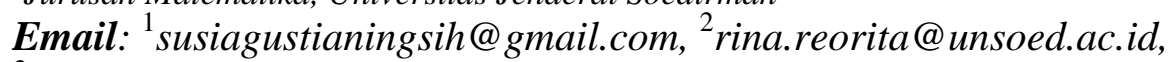

renny.unsoed@gmail.com 


\section{Susi Agustianingsih, Rina Reorita, Renny}

\section{Pendahuluan}

Penyakit menular merupakan penyakit infeksi yang dapat mempengaruhi kesehatan manusia. Penyakit ini disebabkan oleh bakteri, parasit, jamur, dan virus yang menyebar melalui kontak langsung dengan penderita seperti batuk dan bersin [2]. Contoh penyakit menular diantaranya adalah campak, cacar, TBC, rubella, polio, dan pertusis. Salah satu faktor epidemiologi dan demografi yang mempengaruhi penularan penyakit adalah terjadinya imigrasi [1]. Banyaknya kelahiran warga negara dan imigran yang masuk tanpa diberi vaksin mengakibatkan penambahan jumlah populasi individu rentan yang dapat terinfeksi penyakit. Hal ini disebabkan terjadinya kontak antara individu rentan dengan individu terinfeksi yang tidak dikarantina sehingga menimbulkan wabah penyakit pada suatu populasi. Mewabahnya penyakit yang dapat menginfeksi individu dalam populasi selama periode yang singkat disebut dengan epidemi, sedangkan suatu keadaan dimana wabah penyakit secara menetap berada pada populasi tertentu selama jangka waktu panjang disebut dengan endemik [3].

Salah satu strategi pencegahan penyebaran penyakit menular adalah dengan mengkaji perilaku dinamik penyebaran penyakit tersebut. Dinamika penyebaran penyakit dapat direpresentasikan ke dalam sebuah model matematika. Model matematika merupakan salah satu alat yang dapat membantu mempermudah menyelesaikan masalah dalam kehidupan nyata. Masalah tersebut dapat dinyatakan ke dalam model matematis menggunakan asumsi-asumsi tertentu untuk mengetahui bagaimana penyebaran suatu penyakit menular [4].

Model yang digunakan untuk menganalisa penyebaran penyakit ini salah satunya adalah model SIR. Dalam pembentukan model ini, populasi manusia dibagi menjadi tiga kelompok individu, yaitu kelompok individu rentan (susceptible), kelompok individu terinfeksi (infective), dan kelompok individu sembuh (recovery). Individu yang telah terinfeksi suatu penyakit, baik yang dikarantina atau tidak dikarantina dapat mengalami kesembuhan apabila diberi suatu pengobatan. Selain itu, warga negara yang baru lahir dan imigran yang baru masuk dengan diberi vaksin merupakan individu sembuh. Pemberian obat dan vaksin sangat mempengaruhi kemampuan virus dalam menginfeksi penderita, sehingga harus diberikan sesuai dengan kebutuhan. Oleh karena itu, perlu dilakukan kontrol terhadap pemberian obat, karantina, dan vaksin. Tujuannya adalah untuk meminimalisir penularan penyakit dan jumlah individu terinfeksi dengan biaya minimum.

Penelitian tentang kontrol optimal pada model SIR telah banyak dilakukan guna meminimumkan jumlah individu terinfeksi. Salah satunya adalah penelitian Anggriani, dkk [1] yang menjelaskan tentang kontrol optimal pada model epidemik SIR dengan pengaruh vaksinasi dan faktor imigrasi. Hasil yang diperoleh adalah kontrol pengobatan dan vaksinasi berpengaruh pada berkurangnya jumlah individu rentan dan terinfeksi, sehingga akan meningkatkan jumlah individu sembuh. Pada penelitian ini, model tersebut dimodifikasi dengan menambahkan pengaruh karantina terhadap individu yang terinfeksi. Hal ini bertujuan agar penyebaran penyakit dapat semakin ditekan.

Pada penelitian ini dibahas kontrol optimal model SIR dengan pengaruh vaksinasi, karantina, dan faktor imigrasi menggunakan prinsip maksimum Pontryagin. Prinsip maksimum Pontryagin merupakan suatu prinsip yang digunakan untuk menyelesaikan kontrol optimal pada model SIR dengan pemberian kontrol semaksimal/seminimal mungkin sesuai fungsi tujuan. Prinsip ini memiliki kelebihan yaitu dapat menyatakan kondisi yang diperlukan agar diperoleh kontrol yang paling optimal sehingga dapat meminimumkan fungsi tujuan. 


\section{Susi Agustianingsih, Rina Reorita, Renny}

\section{Model Matematika}

Penyebaran penyakit menular merupakan salah satu masalah yang dapat dinyatakan dalam sebuah model matematika menggunakan asumsi-asumsi tertentu. Asumsi yang digunakan dalam penelitian ini merupakan pengembangan dari penelitian Anggriani, dkk [1] dengan menambahkan asumsi individu terinfeksi yang dikarantina tidak dapat menularkan penyakit. Selain itu, individu yang telah terinfeksi suatu penyakit, baik yang dikarantina atau tidak dikarantina akan mendapatkan tingkat kesembuhan yang sama.

Dari asumsi-asumsi tersebut dapat dibentuk alur penyebaran penyakit pada model SIR yang disajikan dalam Gambar 1 berikut.

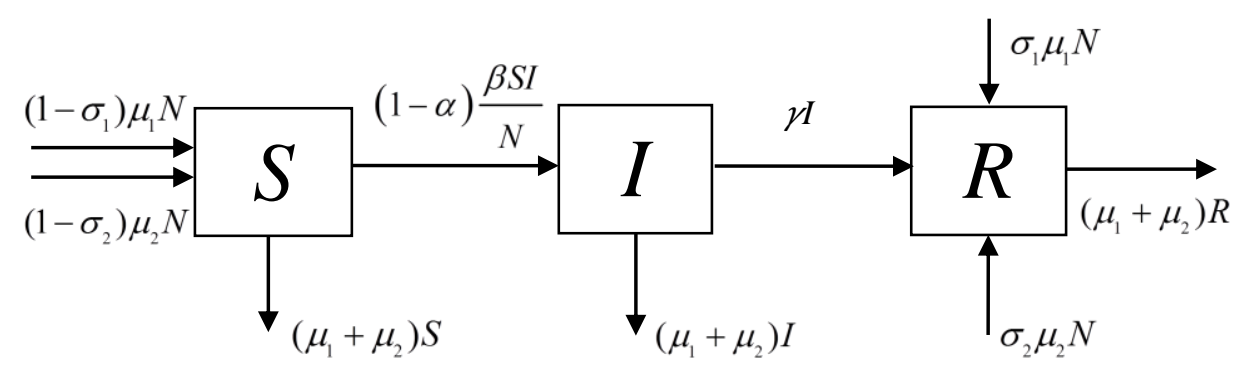

Gambar 1 Alur penyebaran penyakit dengan pengaruh vaksinasi, karantina, dan faktor

Variabel dan parameter yang digunakan pada model SIR dengan pengaruh vaksinasi, karantina, dan faktor imigrasi disajikan dalam Tabel 1.

Tabel 1 Variabel dan parameter yang digunakan pada model SIR dengan pengaruh vaksinasi, karantina, dan faktor imigrasi

\begin{tabular}{clc}
\hline Notasi & \multicolumn{1}{c}{ Keterangan } & Satuan \\
\hline$N$ & Total individu dalam populasi & Jiwa \\
$S$ & Jumlah individu rentan & Jiwa \\
$I$ & Jumlah individu terinfeksi & Jiwa \\
$R$ & Jumlah individu sembuh & Jiwa \\
$\mu_{1}$ & Tingkat kelahiran warga negara & per satuan waktu \\
$\mu_{2}$ & Tingkat imigran yang masuk ke dalam populasi & per satuan waktu \\
$\sigma_{1}$ & Proporsi warga negara yang divaksin & - \\
$\sigma_{2}$ & Proporsi imigran yang divaksin & - \\
$\alpha$ & Proporsi individu terinfeksi yang dikarantina & per satuan waktu \\
$\beta$ & Tingkat penularan penyakit & per satuan waktu \\
$\gamma$ & Tingkat kesembuhan individu terinfeksi & \\
\hline
\end{tabular}

Berdasarkan asumsi serta alur penyebaran penyakit pada Gambar 1, diperoleh model SIR dengan pengaruh vaksinasi, karantina, dan faktor imigrasi yaitu sebagai berikut 


\section{Susi Agustianingsih, Rina Reorita, Renny}

$$
\begin{aligned}
& \frac{d S}{d t}=\left(1-\sigma_{1}\right) \mu_{1} N+\left(1-\sigma_{2}\right) \mu_{2} N-\frac{(1-\alpha) \beta S I}{N}-\left(\mu_{1}+\mu_{2}\right) S \\
& \frac{d I}{d t}=\frac{(1-\alpha) \beta S I}{N}-\gamma I-\left(\mu_{1}+\mu_{2}\right) I \\
& \frac{d R}{d t}=\sigma_{1} \mu_{1} N+\sigma_{2} \mu_{2} N+\gamma I-\left(\mu_{1}+\mu_{2}\right) R
\end{aligned}
$$

dengan $N=S+I+R$.

Karena variabel $S, I$, dan $R$ pada sistem (1) memiliki dimensi yang sama, maka sistem (1) dapat dinormalisasi menjadi suatu variabel baru menggunakan proporsi

$$
s=\frac{S}{N} \Leftrightarrow S=s N, \quad i=\frac{I}{N} \Leftrightarrow I=i N, \text { dan } r=\frac{R}{N} \Leftrightarrow R=r N,
$$

dengan $s+i+r=\frac{S}{N}+\frac{I}{N}+\frac{R}{N}=1$, sehingga diperoleh model SIR yang telah dinormalisasi yaitu sebagai berikut

$$
\begin{aligned}
& \frac{d s}{d t}=\left(1-\sigma_{1}\right) \mu_{1}+\left(1-\sigma_{2}\right) \mu_{2}-(1-\alpha) \beta s i-\left(\mu_{1}+\mu_{2}\right) s \\
& \frac{d i}{d t}=(1-\alpha) \beta s i-\gamma i-\left(\mu_{1}+\mu_{2}\right) i \\
& \frac{d r}{d t}=\sigma_{1} \mu_{1}+\sigma_{2} \mu_{2}+\gamma i-\left(\mu_{1}+\mu_{2}\right) r .
\end{aligned}
$$

Tujuan kontrol optimal pada model SIR dengan pengaruh vaksinasi, karantina, dan faktor imigrasi adalah untuk meminimalisir penularan penyakit dan jumlah individu terinfeksi dengan biaya minimum. Oleh karena itu, diberikan fungsi kontrol $u_{1}(t), u_{2}(t), u_{3}(t)$, dan $u_{4}(t)$ pada sistem (2). Kontrol $u_{1}(t)$ merupakan upaya mengurangi jumlah individu terinfeksi dengan melakukan pengobatan, $u_{2}(t)$ merupakan kontrol vaksinasi untuk warga negara, $u_{3}(t)$ merupakan kontrol vaksinasi untuk imigran, dan $u_{4}(t)$ merupakan kontrol karantina.

Berdasarkan model SIR yang telah dinormalisasi pada sistem (2), maka dibentuk model SIR yang dilengkapi dengan variabel kontrol yaitu sebagai berikut

$$
\begin{aligned}
& \frac{d s}{d t}=\left(1-\left(1+u_{2}\right) \sigma_{1}\right) \mu_{1}+\left(1-\left(1+u_{3}\right) \sigma_{2}\right) \mu_{2}-\left(1-\left(1+u_{4}\right) \alpha\right) \beta s i-\left(\mu_{1}+\mu_{2}\right) s \\
& \frac{d i}{d t}=\left(1-\left(1+u_{4}\right) \alpha\right) \beta s i-u_{1} \gamma i-\left(\mu_{1}+\mu_{2}\right) i \\
& \frac{d r}{d t}=\left(1+u_{2}\right) \sigma_{1} \mu_{1}+\left(1+u_{3}\right) \sigma_{2} \mu_{2}+u_{1} \gamma i-\left(\mu_{1}+\mu_{2}\right) r .
\end{aligned}
$$

Sistem persamaan (3) disebut sebagai persamaan state. Selanjutnya, akan dimodelkan suatu fungsi tujuan yang menjelaskan bahwa akan diminimumkan jumlah individu terinfeksi melalui proses karantina, pengobatan, dan vaksinasi dengan biaya minimum. Biaya yang dikeluarkan memiliki hubungan tidak linier dengan jumlah individu terinfeksi, sehingga fungsi biaya dimodelkan non linier dan dipilih fungsi kuadratik $\mathbf{u}^{2}$. Hal ini disebabkan besarnya karantina, pengobatan, dan vaksin menimbulkan biaya yang dikeluarkan semakin besar, tetapi jumlah individu terinfeksi semakin kecil atau minimum. 


\section{Susi Agustianingsih, Rina Reorita, Renny}

Fungsi tujuan untuk model kontrol pada sistem persamaan (3) didefinisikan sebagai berikut

$$
J=\min \int_{0}^{t_{f}}\left(A i+C_{1} u_{1}^{2}+C_{2} u_{2}^{2}+C_{3} u_{3}^{2}+C_{4} u_{4}^{2}\right) d t
$$

dan kondisi batas berdasarkan penelitian Anggriani et al., (2015:114)

$$
\begin{aligned}
& 0 \leq t \leq t_{f} \\
& 1 \leq u_{1} \leq 2 \\
& 0 \leq u_{2} \leq 1 \\
& 0 \leq u_{3} \leq 1 \\
& 0 \leq u_{4} \leq 1 \\
& C_{1}, C_{2}, C_{3}, C_{4}>0
\end{aligned}
$$

dengan $t_{f}$ adalah waktu akhir, $A$ merupakan bobot yang dikenakan pada individu terinfeksi, $i$ merupakan proporsi jumlah individu terinfeksi dengan total populasi individu, $C_{1}$ merupakan bobot biaya pengobatan untuk warga negara maupun imigran, $C_{2}$ merupakan bobot biaya vaksinasi untuk warga negara, $C_{3}$ merupakan bobot biaya vaksinasi untuk imigran, dan $C_{4}$ merupakan bobot biaya karantina untuk warga negara maupun imigran.

Kondisi batas kontrol pengobatan $u_{1}$ sebesar $1 \leq u_{1} \leq 2$ menunjukkan besarnya tingkat efektifitas pemberian obat dalam menyembuhkan individu terinfeksi. Kondisi batas kontrol vaksinasi untuk warga negara $u_{2}$ sebesar $0 \leq u_{2} \leq 1$ menunjukkan besarnya tingkat efektifitas pemberian vaksin untuk warga negara yang baru lahir agar menjadi kelompok individu sembuh. Kondisi batas kontrol vaksinasi untuk imigran $u_{3}$ sebesar $0 \leq u_{3} \leq 1$ menunjukkan besarnya tingkat efektifitas pemberian vaksin untuk imigran agar menjadi kelompok individu sembuh. Kondisi batas kontrol karantina $u_{4}$ sebesar $0 \leq u_{4} \leq 1$ menunjukkan besarnya tingkat efektifitas pemberian karantina terhadap individu terinfeksi sehingga penularan penyakit dapat dicegah.

\section{Penyelesaian Kontrol Optimal pada Model SIR}

Berdasarkan prinsip maksimum Pontryagin, langkah pertama untuk menyelesaikan kontrol optimal pada model SIR yaitu membentuk persamaan Hamiltonian. Persamaan Hamiltonian diperoleh dari fungsi tujuan ditambahkan dengan hasil perkalian vektor adjoin dan persamaan state, sehingga diperoleh bentuk persamaan Hamiltonian yaitu sebagai berikut

$$
\begin{aligned}
H(t, \mathbf{x}(t), \mathbf{u}(t), \lambda(t))= & A i+C_{1} u_{1}^{2}+C_{2} u_{2}^{2}+C_{3} u_{3}^{2}+C_{4} u_{4}^{2}+ \\
& \lambda_{1}\left(\left(1-\left(1+u_{2}\right) \sigma_{1}\right) \mu_{1}+\left(1-\left(1+u_{3}\right) \sigma_{2}\right) \mu_{2}-\left(1-\left(1+u_{4}\right) \alpha\right) \beta s i-\left(\mu_{1}+\mu_{2}\right) s\right)+ \\
& \lambda_{2}\left(\left(1-\left(1+u_{4}\right) \alpha\right) \beta s i-u_{1} \gamma i-\left(\mu_{1}+\mu_{2}\right) i\right)+ \\
& \lambda_{3}\left(\left(1+u_{2}\right) \sigma_{1} \mu_{1}+\left(1+u_{3}\right) \sigma_{2} \mu_{2}+u_{1} \gamma i-\left(\mu_{1}+\mu_{2}\right) r\right) .
\end{aligned}
$$

Melalui persamaan (5) dapat diperoleh syarat perlu yaitu berupa persamaan co-state dan kondisi optimal dari sistem. Persamaan co-state atau sistem adjoint dari sistem persamaan (3) adalah sebagai berikut 


\section{Susi Agustianingsih, Rina Reorita, Renny}

$$
\begin{aligned}
& \frac{d \lambda_{1}}{d t}=\lambda_{1}\left(\left(1-\left(1+u_{4}\right) \alpha\right) \beta i+\left(\mu_{1}+\mu_{2}\right)\right)+\lambda_{2}\left(-\left(1-\left(1+u_{4}\right) \alpha\right) \beta i\right) \\
& \frac{d \lambda_{2}}{d t}=-A+\lambda_{1}\left(\left(1-\left(1+u_{4}\right) \alpha\right) \beta s\right)+\lambda_{2}\left(-\left(1-\left(1+u_{4}\right) \alpha\right) \beta s+u_{1} \gamma+\left(\mu_{1}+\mu_{2}\right)\right)+\lambda_{3}\left(-u_{1} \gamma\right) \\
& \frac{d \lambda_{3}}{d t}=\lambda_{3}\left(\mu_{1}+\mu_{2}\right)
\end{aligned}
$$

Kondisi yang optimal pada prinsip maksimum Pontryagin dapat ditentukan dengan cara menurunkan persamaan (5) terhadap masing-masing variabel kontrol. Kondisi optimal yang harus dipenuhi adalah

$$
\frac{\partial H}{\partial \mathbf{u}}=0
$$

dengan vektor $\mathbf{u}$ menyatakan bahwa kontrol yang digunakan berupa pengobatan, vaksinasi, dan karantina.

Misalkan $u_{1}^{*}$ adalah nilai optimal dari kontrol $u_{1}$ atau dengan kata lain nilai $u_{1}$ yang mengakibatkan $\frac{\partial H}{\partial u_{1}}=0$. Dengan demikian diperoleh kondisi optimal yang harus dipenuhi pada kontrol pengobatan yaitu sebagai berikut

$$
\begin{aligned}
& \frac{\partial H}{\partial u_{1}}=0 \\
& \Leftrightarrow 2 C_{1} u_{1}-\lambda_{2} \gamma i+\lambda_{3} \gamma i=0 \\
& \Leftrightarrow u_{1}=\frac{\gamma i\left(\lambda_{2}-\lambda_{3}\right)}{2 C_{1}}
\end{aligned}
$$

sehingga

$$
u_{1}^{*}=\frac{\gamma i\left(\lambda_{2}-\lambda_{3}\right)}{2 C_{1}}
$$

Berdasarkan kondisi batas variabel kontrol $1 \leq u_{1} \leq 2$, maka batas variabel kontrol optimal $1 \leq u_{1}^{*} \leq 2$. Dengan demikian solusi $u_{1}$ yang optimal yaitu

$$
u_{1}^{*}=\left\{\begin{array}{cc}
1 \quad, \frac{\gamma i\left(\lambda_{2}-\lambda_{3}\right)}{2 C_{1}} \leq 1 \\
\frac{\gamma i\left(\lambda_{2}-\lambda_{3}\right)}{2 C_{1}}, & 1<\frac{\gamma i\left(\lambda_{2}-\lambda_{3}\right)}{2 C_{1}}<2 \\
2 & , \frac{\gamma i\left(\lambda_{2}-\lambda_{3}\right)}{2 C_{1}} \geq 2
\end{array} .\right.
$$

Nilai kontrol optimal pada persamaan (7) dapat dituliskan dalam bentuk

$$
u_{1}^{*}=\min \left\{\max \left\{1, \frac{\gamma i\left(\lambda_{2}-\lambda_{3}\right)}{2 C_{1}}\right\}, 2\right\} \text {. }
$$




\section{Susi Agustianingsih, Rina Reorita, Renny}

Selanjutnya, misalkan $u_{2}{ }^{*}$ adalah nilai optimal dari kontrol $u_{2}$ atau dengan kata lain nilai $u_{2}$ yang mengakibatkan $\frac{\partial H}{\partial u_{2}}=0$. Dengan demikian diperoleh kondisi optimal yang harus dipenuhi pada kontrol vaksinasi untuk warga negara yaitu sebagai berikut

$$
\begin{aligned}
& \frac{\partial H}{\partial u_{2}}=0 \\
& \Leftrightarrow 2 C_{2} u_{2}-\lambda_{1} \sigma_{1} \mu_{1}+\lambda_{3} \sigma_{1} \mu_{1}=0 \\
& \Leftrightarrow u_{2}=\frac{\sigma_{1} \mu_{1}\left(\lambda_{1}-\lambda_{3}\right)}{2 C_{2}}
\end{aligned}
$$

sehingga

$$
u_{2}^{*}=\frac{\sigma_{1} \mu_{1}\left(\lambda_{1}-\lambda_{3}\right)}{2 C_{2}}
$$

Berdasarkan kondisi batas variabel kontrol $0 \leq u_{2} \leq 1$, maka batas variabel kontrol optimal $0 \leq u_{2}^{*} \leq 1$. Dengan demikian solusi $u_{2}$ yang optimal yaitu

$$
u_{2}^{*}=\left\{\begin{array}{cc}
0 & , \frac{\sigma_{1} \mu_{1}\left(\lambda_{1}-\lambda_{3}\right)}{2 C_{2}} \leq 0 \\
\frac{\sigma_{1} \mu_{1}\left(\lambda_{1}-\lambda_{3}\right)}{2 C_{2}}, & 0<\frac{\sigma_{1} \mu_{1}\left(\lambda_{1}-\lambda_{3}\right)}{2 C_{2}}<1 \\
1 & , \frac{\sigma_{1} \mu_{1}\left(\lambda_{1}-\lambda_{3}\right)}{2 C_{2}} \geq 1 .
\end{array} .\right.
$$

Nilai kontrol optimal pada persamaan (8) dapat dituliskan dalam bentuk

$$
u_{2}{ }^{*}=\min \left\{\max \left\{0, \frac{\sigma_{1} \mu_{1}\left(\lambda_{1}-\lambda_{3}\right)}{2 C_{2}}\right\}, 1\right\} \text {. }
$$

Selanjutnya, misalkan $u_{3}{ }^{*}$ adalah nilai optimal dari kontrol $u_{3}$ dan $u_{4}{ }^{*}$ adalah nilai optimal dari kontrol $u_{4}$. Dengan cara yang sama, diperoleh

$$
u_{3}^{*}=\left\{\begin{array}{cc}
0 & , \frac{\sigma_{2} \mu_{2}\left(\lambda_{1}-\lambda_{3}\right)}{2 C_{3}} \leq 0 \\
\frac{\sigma_{2} \mu_{2}\left(\lambda_{1}-\lambda_{3}\right)}{2 C_{3}} & , 0<\frac{\sigma_{2} \mu_{2}\left(\lambda_{1}-\lambda_{3}\right)}{2 C_{3}}<1 \\
1 \quad & \frac{\sigma_{2} \mu_{2}\left(\lambda_{1}-\lambda_{3}\right)}{2 C_{3}} \geq 1 .
\end{array}\right.
$$




\section{Susi Agustianingsih, Rina Reorita, Renny}

$$
u_{4}^{*}=\left\{\begin{array}{cc}
0 & , \frac{\alpha \beta \operatorname{si}\left(\lambda_{2}-\lambda_{1}\right)}{2 C_{4}} \leq 0 \\
\frac{\alpha \beta \operatorname{si}\left(\lambda_{2}-\lambda_{1}\right)}{2 C_{4}} & , 0<\frac{\alpha \beta \operatorname{si}\left(\lambda_{2}-\lambda_{1}\right)}{2 C_{4}}<1 \\
1 & , \frac{\alpha \beta \operatorname{si}\left(\lambda_{2}-\lambda_{1}\right)}{2 C_{4}} \geq 1 .
\end{array}\right.
$$

Dengan demikian diperoleh bentuk kontrol $u_{1}(t), u_{2}(t), u_{3}(t)$, dan $u_{4}(t)$ yang akan mengoptimalkan fungsi tujuan yang diberikan yaitu sebagai berikut

$$
\begin{aligned}
& u_{1}^{*}=\min \left\{\max \left\{1, \frac{\gamma i\left(\lambda_{2}-\lambda_{3}\right)}{2 C_{1}}\right\}, 2\right\} \\
& u_{2}^{*}=\min \left\{\max \left\{0, \frac{\sigma_{1} \mu_{1}\left(\lambda_{1}-\lambda_{3}\right)}{2 C_{2}}\right\}, 1\right\} \\
& u_{3}^{*}=\min \left\{\max \left\{0, \frac{\sigma_{2} \mu_{2}\left(\lambda_{1}-\lambda_{3}\right)}{2 C_{3}}\right\}, 1\right\} \\
& u_{4}^{*}=\min \left\{\max \left\{0, \frac{\alpha \beta s i\left(\lambda_{2}-\lambda_{1}\right)}{2 C_{4}}\right\}, 1\right\} .
\end{aligned}
$$

\section{Simulasi Numerik}

Pada penelitian ini, simulasi numerik dilakukan untuk mengetahui pengaruh dari pemberian kontrol pada masing-masing kompartemen terhadap waktu. Selain itu, akan dikaji perbandingan kontrol optimal pada model SIR tanpa faktor karantina dan dengan faktor karantina.

Pada bagian ini dilakukan perbandingan simulasi kontrol optimal model SIR dengan pengaruh vaksinasi dan faktor imigrasi tanpa karantina, seperti pada penelitian Anggriani, dkk [1] dan kontrol optimal pada model SIR dengan pengaruh vaksinasi, karantina, dan faktor imigrasi menggunakan sistem persamaan (2) dan (3). Simulasi model pada penelitian Anggriani, dkk [1] menggunakan tiga kontrol, yaitu kontrol $u_{1}$ yang menyatakan upaya untuk mengurangi jumlah individu terinfeksi dengan melakukan pengobatan, kontrol $u_{2}$ yang menyatakan kontrol vaksinasi untuk warga negara, dan kontrol $u_{3}$ yang menyatakan kontrol vaksinasi untuk imigran, sedangkan pada penelitian ini digunakan empat kontrol yaitu dengan menambahkan kontrol karantina $u_{4}$.

Tujuan dilakukan simulasi ini adalah untuk mengetahui pengaruh kontrol pengobatan, kontrol vaksinasi untuk warga negara, dan kontrol vaksinasi untuk imigran sehingga dapat meminimalisir penularan penyakit dan jumlah individu terinfeksi dengan biaya minimum. Namun, dengan adanya pengaruh kontrol karantina diharapkan lebih meminimalisir penularan penyakit dan jumlah individu terinfeksi dengan biaya yang lebih minimum.

Nilai-nilai parameter yang digunakan dalam simulasi model mengacu pada penelitian Anggriani, dkk [1] yang disajikan dalam Tabel 2 dan Tabel 3. 


\section{Susi Agustianingsih, Rina Reorita, Renny}

Tabel 2 Nilai awal kontrol optimal model SIR tanpa dan dengan faktor karantina

\begin{tabular}{cc}
\hline Variabel & Nilai awal \\
\hline$s(0)$ & 0,8 \\
$i(0)$ & 0,2 \\
$r(0)$ & 0 \\
\hline
\end{tabular}

Tabel 3 Nilai parameter kontrol optimal model SIR tanpa dan dengan faktor karantina

\begin{tabular}{cc}
\hline Parameter & Nilai parameter \\
\hline$\mu_{1}$ & 0,4 \\
$\mu_{2}$ & 0,15 \\
$\sigma_{1}$ & 0,3 \\
$\sigma_{2}$ & 0,3 \\
$\alpha$ & 0,3 \\
$\beta$ & 0,8 \\
$\gamma$ & 0,03 \\
$A$ & 40 \\
$C_{1}$ & 1 \\
$C_{2}$ & 1 \\
$C_{3}$ & 1 \\
$C_{4}$ & 1 \\
\hline
\end{tabular}

Berikut ini merupakan hasil perbandingan simulasi pada proporsi individu terinfeksi tanpa faktor karantina dan dengan faktor karantina yang disajikan dalam Gambar 2 berikut.

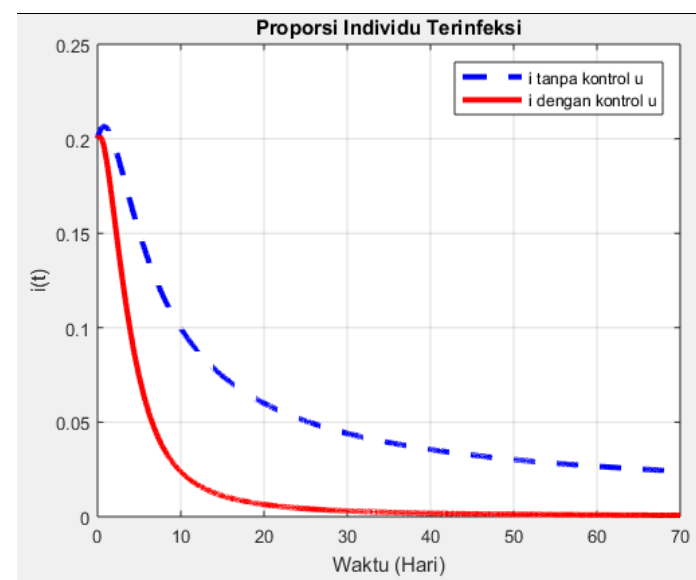

(a)

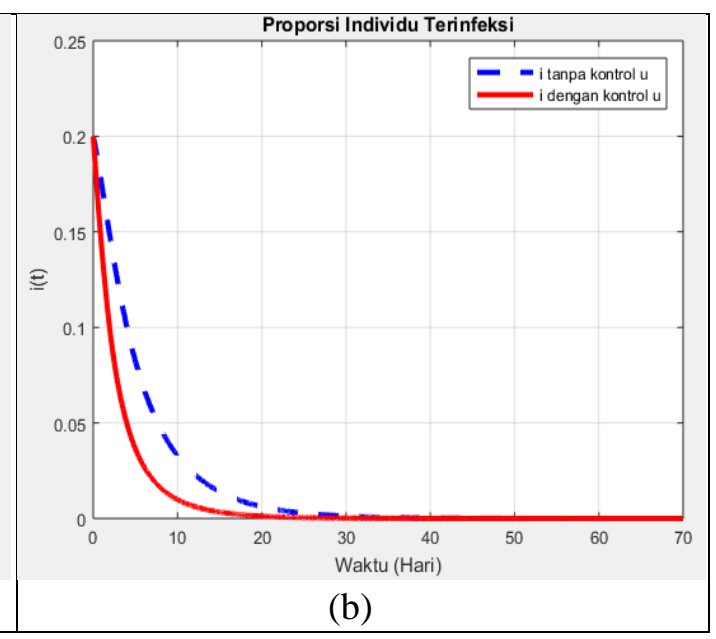

(b)

Gambar 2 Perbandingan proporsi individu terinfeksi terhadap waktu pada

(a) tanpa faktor karantina menggunakan pengaruh kontrol $u_{1}(t), u_{2}(t), u_{3}(t)$, dan

(b) dengan faktor karantina menggunakan pengaruh kontrol $u_{1}(t), u_{2}(t), u_{3}(t), u_{4}(t)$ 


\section{Susi Agustianingsih, Rina Reorita, Renny}

Gambar 2 menjelaskan tentang perbandingan proporsi individu terinfeksi tanpa faktor karantina dan dengan faktor karantina beserta pengontrol yang diberikan. Garis putus-putus pada Gambar 2(a) menunjukkan proporsi individu terinfeksi tanpa pemberian kontrol $u_{1}(t), u_{2}(t)$, dan $u_{3}(t)$ meningkat hingga 0,21 pada waktu awal kemudian bergerak menurun hingga proporsi individu terinfeksi sebanyak 0,024 pada waktu akhir, sehingga penyakit akan selalu ada dalam jangka waktu $t=70$. Akan tetapi, garis putus-putus pada Gambar 2(b) menunjukkan proporsi individu terinfeksi tanpa pemberian kontrol $u_{1}(t), u_{2}(t), u_{3}(t)$, dan $u_{4}(t)$ bergerak lebih menurun mendekati nol pada waktu akhir $t=70$. Dengan demikian dapat disimpulkan bahwa pengaruh faktor karantina akan mempercepat penurunan proporsi individu terinfeksi.

Sementara itu, garis pada Gambar 2(a) menunjukkan proporsi individu terinfeksi dengan pemberian kontrol $u_{1}(t), u_{2}(t)$, dan $u_{3}(t)$ meningkat hingga 0,2014 pada waktu awal dan bergerak menurun hingga proporsi individu terinfeksi mendekati nol pada $t=70$. Akan tetapi, garis pada Gambar 2(b) menunjukkan proporsi individu terinfeksi dengan pemberian kontrol $u_{1}(t), u_{2}(t), u_{3}(t)$, dan $u_{4}(t)$ lebih cepat mengalami penurunan mendekati nol dari waktu awal hingga waktu akhir $t=70$. Dengan demikian dapat disimpulkan bahwa pemberian kontrol pada faktor karantina dapat mempercepat penurunan proporsi individu terinfeksi.

Berikut ini akan dilakukan perbandingan simulasi masing-masing kontrol optimal yang mempengaruhi proporsi individu terinfeksi. Kontrol optimal tersebut mengkaji tentang tingkat efektifitas optimal pada pemberian obat, vaksinasi untuk warga negara, vaksinasi untuk imigran, dan karantina. Perbandingan kontrol optimal pengobatan $u_{1}^{*}$ tanpa faktor karantina dan dengan faktor karantina disajikan pada Gambar 3 berikut.

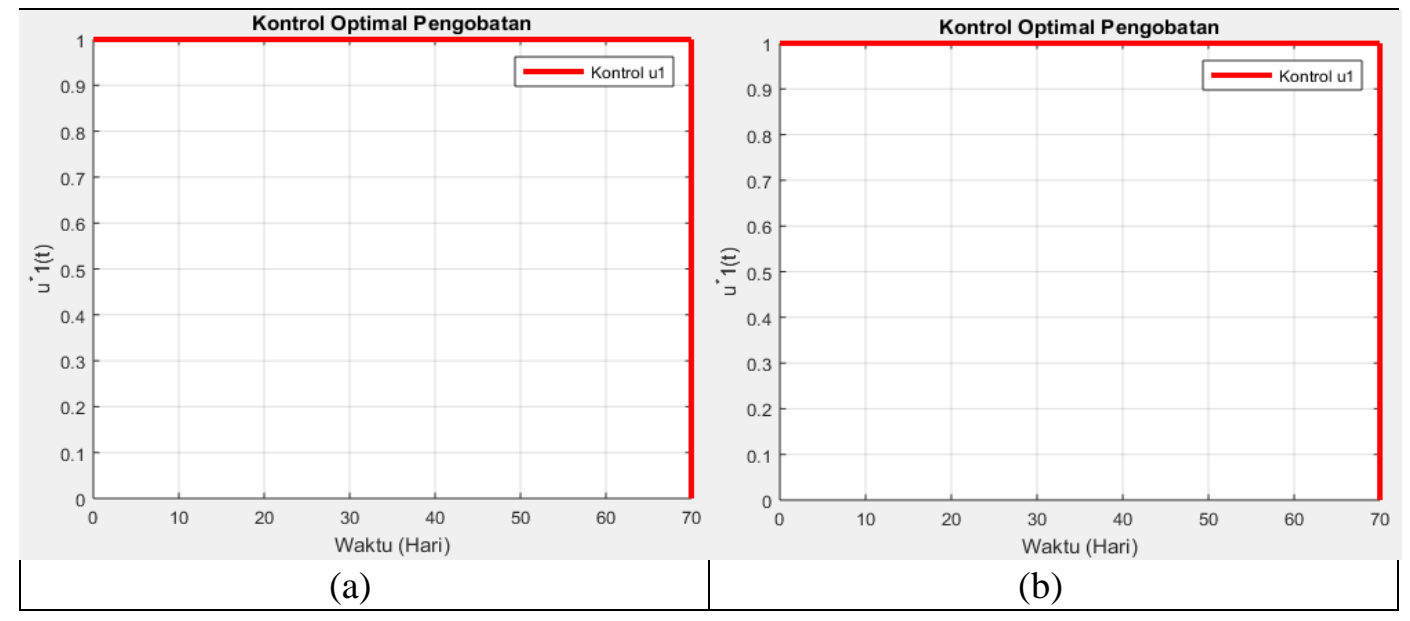

Gambar 3 Perbandingan kontrol optimal pengobatan (a) tanpa faktor karantina dan (b) dengan faktor karantina

Gambar 3 menjelaskan tentang perbandingan kontrol optimal pengobatan tanpa faktor karantina dan dengan faktor karantina. Berdasarkan grafik simulasi pada Gambar 3(a) dan Gambar 3(b) dapat disimpulkan bahwa besarnya tingkat efektifitas optimal pada pemberian obat, baik kontrol pengobatan tanpa faktor karantina maupun dengan faktor karantina sama-sama mencapai tingkat minimum sebesar 1 dan konstan dari hari pertama hingga hari ke 70 kemudian berhenti. Pemberian kontrol optimal pengobatan pada individu terinfeksi membantu dalam 


\section{Susi Agustianingsih, Rina Reorita, Renny}

menghambat penyebaran penyakit sehingga menurunkan proporsi individu terinfeksi mendekati nol.

Selanjutnya akan dilakukan perbandingan simulasi kontrol optimal vaksinasi untuk warga negara yang mempengaruhi proporsi individu terinfeksi. Perbandingan kontrol optimal vaksinasi untuk warga negara $u_{2}{ }^{*}$ tanpa faktor karantina dan dengan faktor karantina disajikan pada Gambar 4 berikut.

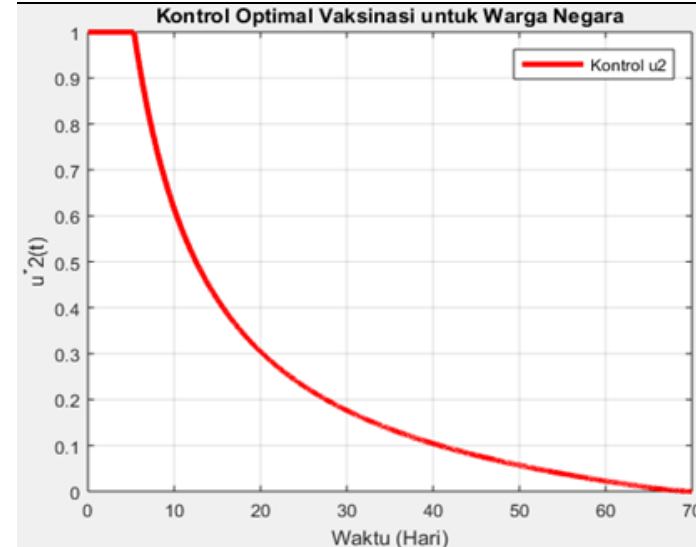

(a)

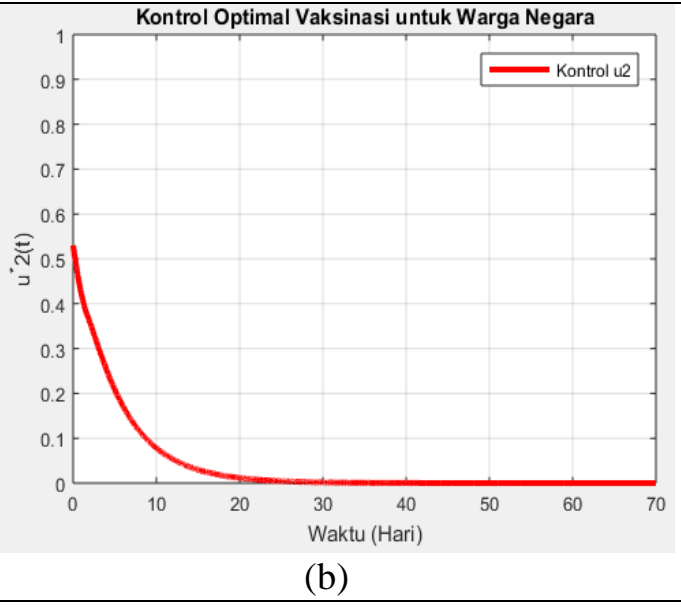

(b)

Gambar 4 Perbandingan kontrol optimal vaksinasi untuk warga negara (a) tanpa faktor karantina dan (b) dengan faktor karantina

Berdasarkan grafik simulasi pada Gambar 4(a) dapat disimpulkan bahwa besarnya tingkat efektifitas optimal pada pemberian vaksin untuk warga negara mencapai tingkat maksimum sebesar 1 dari hari pertama pemberian kontrol sampai mendekati hari ke-6, kemudian tingkat efektifitas terhadap pemberian vaksin untuk warga negara berangsur-angsur menurun hingga hari ke-70 sehingga tidak ada lagi kontrol vaksinasi untuk warga negara yang diberikan atau nol. Akan tetapi dengan diberikan faktor karantina pada Gambar 4(b) menunjukkan tingkat efektifitas optimal pada pemberian vaksin untuk warga negara hanya sebesar 0,53 dan berangsur-angsur menurun hingga hari ke-70 sehingga tidak ada lagi kontrol vaksinasi untuk warga negara yang diberikan atau nol.

Selain perbandingan kontrol optimal vaksinasi untuk warga negara di atas, pada bagian ini akan dilakukan perbandingan simulasi kontrol optimal vaksinasi untuk imigran yang mempengaruhi proporsi individu terinfeksi. Perbandingan kontrol optimal vaksinasi untuk imigran $u_{3}{ }^{*}$ tanpa faktor karantina dan dengan faktor karantina disajikan pada Gambar 5 berikut. 


\section{Susi Agustianingsih, Rina Reorita, Renny}

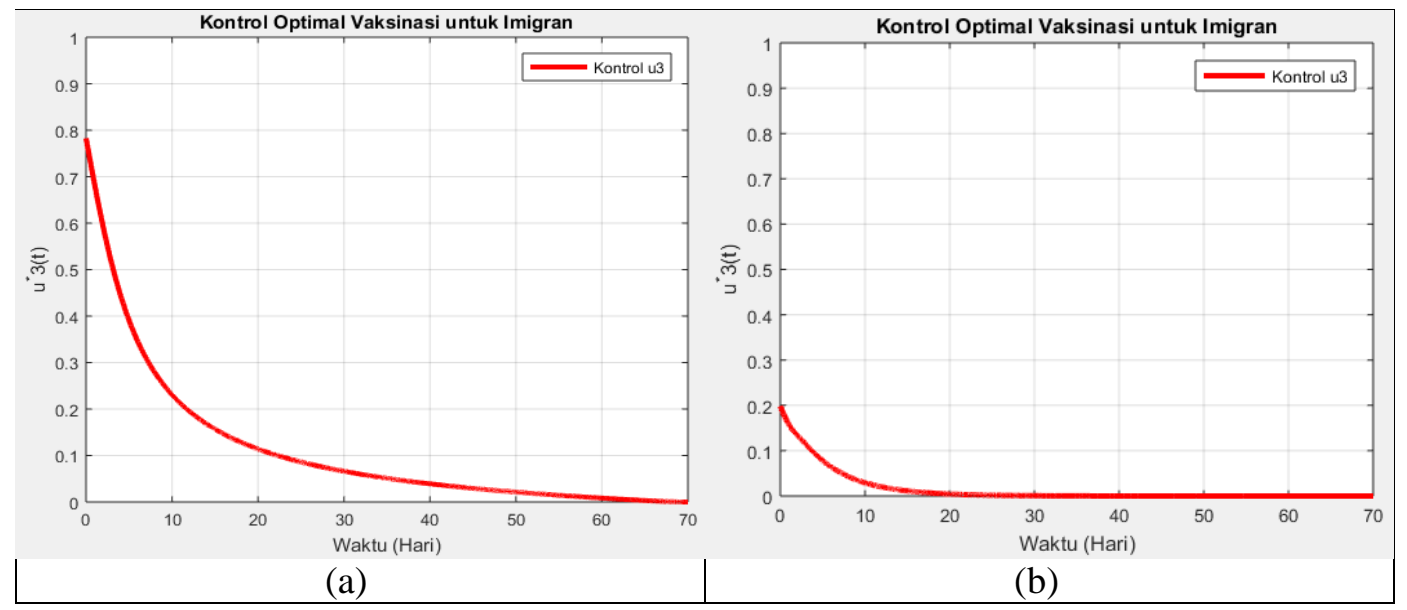

Gambar 5 Perbandingan kontrol optimal vaksinasi untuk imigran (a) tanpa faktor karantina dan (b) dengan faktor karantina

Berdasarkan grafik simulasi pada Gambar 5(a) dapat disimpulkan bahwa tingkat efektifitas optimal pada pemberian vaksin untuk imigran mencapai tingkat maksimum sebesar 0,783 dari hari pertama kemudian berangsur-angsur menurun hingga hari ke-70, sehingga tidak ada lagi kontrol vaksinasi untuk imigran yang diberikan atau nol. Sementara itu, dengan ditambahkannya faktor karantina pada Gambar 5(b) menunjukkan bahwa tingkat efektifitas optimal pada pemberian vaksin untuk imigran hanya sebesar 0,1986 dari hari pertama kemudian berangsur-angsur menurun hingga hari ke-70, sehingga tidak ada lagi kontrol vaksinasi untuk imigran yang diberikan atau nol.

Berikut ini dilakukan simulasi kontrol optimal karantina $u_{4}{ }^{*}$ yang disajikan dalam Gambar 6 berikut.

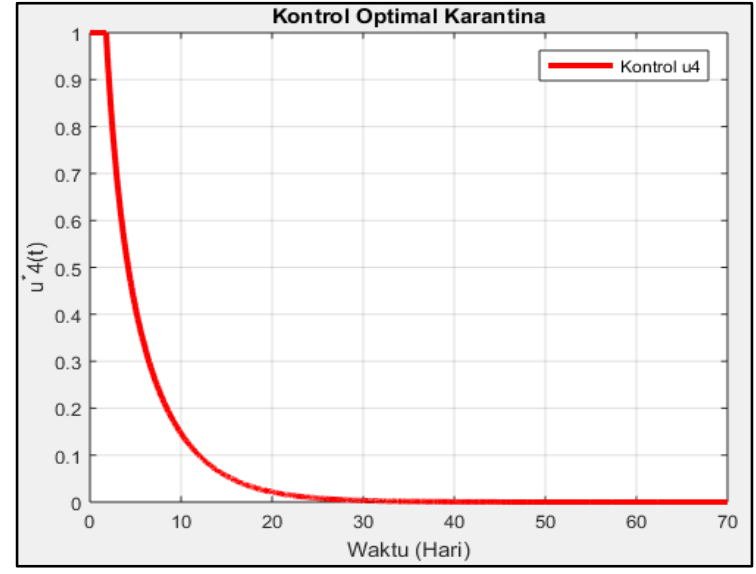

Gambar 6 Grafik kontrol optimal karantina terhadap waktu

Berdasarkan grafik simulasi pada Gambar 6 dapat disimpulkan bahwa tingkat efektifitas optimal terhadap pemberian kontrol karantina mencapai tingkat maksimum sebesar 1 dari hari pertama pemberian kontrol sampai mendekati hari ke-2, kemudian tingkat efektifitas pemberian karantina berangsur-angsur menurun hingga hari ke-70 sehingga tidak ada lagi kontrol karantina yang diberikan atau nol. 


\section{Susi Agustianingsih, Rina Reorita, Renny}

Dalam meminimalisir penularan penyakit dan proporsi individu terinfeksi, pemberian kontrol optimal pengobatan $u_{1}{ }^{*}$, kontrol optimal vaksinasi untuk warga negara $u_{2}{ }^{*}$, kontrol optimal vaksinasi untuk imigran $u_{3}{ }^{*}$, dan kontrol optimal karantina $u_{4}{ }^{*}$ mempengaruhi besarnya nilai fungsi tujuan $J$. Berikut ini perbandingan fungsi tujuan $J$ tanpa faktor karantina dan dengan faktor karantina yang disajikan pada Gambar 7 berikut.

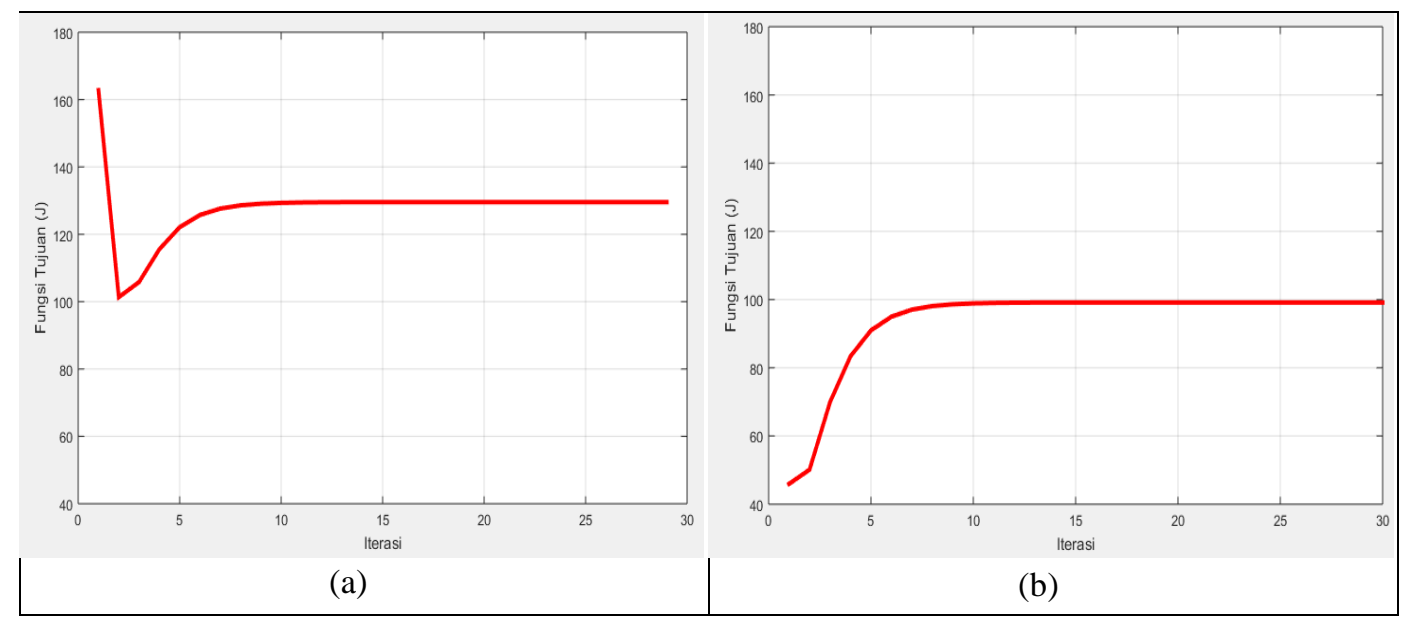

Gambar 7 Perbandingan fungsi tujuan (a) tanpa faktor karantina dan (b) dengan faktor karantina

Grafik simulasi model pada Gambar 7(a) menunjukkan bahwa dalam mengendalikan penyebaran suatu penyakit, penerapan kontrol optimal pengobatan, kontrol optimal vaksinasi untuk warga negara, dan kontrol optimal vaksinasi untuk imigran mengakibatkan fungsi tujuan $J$ bernilai minimum yaitu sebesar 129,5692 pada akhir simulasi saat iterasi ke-29. Sementara itu, dengan ditambahkannya faktor karantina pada simulasi Gambar 7(b) mengakibatkan fungsi tujuan $J$ bernilai lebih rendah yaitu sebesar 99,15028 pada akhir simulasi saat iterasi ke-30.

\section{Kesimpulan}

Hasil penelitian menunjukkan bahwa dengan menggunakan prinsip maksimum Pontryagin, diperoleh sistem yang optimal sedemikian sehingga pemberian kontrol optimal pada model SIR dengan faktor karantina lebih berpengaruh dalam mempercepat penurunan proporsi individu terinfeksi dengan biaya yang lebih minimum. Oleh sebab itu, kontrol optimal pada model SIR dengan pengaruh vaksinasi, karantina, dan faktor imigrasi lebih baik dalam meminimalisir jumlah individu terinfeksi dibandingkan dengan kontrol optimal pada model SIR dengan pengaruh vaksinasi dan faktor imigrasi.

\section{Daftar Pustaka}

[1] Anggriani, N., Supriatna, A., Subartini, B., dan Wulantini, R. 2015. Kontrol Optimum pada Model Epidemik SIR dengan Pengaruh Vaksinasi dan Faktor Imigrasi. Jurnal Matematika Integratif. 11(2): 111-118.

[2] Murray, J. D. 2002. Mathematical Biology: I An Introduction, Third Edition. USA: Springer. 


\section{Susi Agustianingsih, Rina Reorita, Renny}

[3] Salmani, M. 1995. A Model for Disease Transmission in a Patchy Environment. Thesis. Department of Mathematics and Statistics, University of Isfahan, Iran.

[4] Sari, I., dan Tasman, H. 2014. Model Epidemik SIR untuk Penyakit yang Menular secara Horizontal dan Vertikal. Makalah. Dalam: Prosiding Konferensi Nasional Matematika XVII di ITS, 11-14 Juni. 